
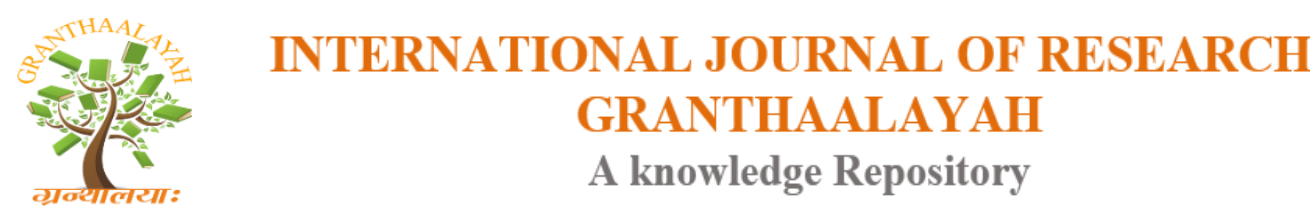

Science

\title{
GROUNDWATER QUALITY ASSESSMENT FOR IRRIGATION PURPOSES AT THE WESTERN PORTION OF THE RIVER NILE- MINIA DISTRICT- EGYPT
}

\author{
Mamdouh Salama Morsi *1 \\ ${ }^{* 1}$ Department of Mines and Quarry, Minia Governorate- Egypt
}

\begin{abstract}
The main goal of this research is assessment the groundwater resources for irrigation purposes at the western portion of the River Nile-Minia district- Egypt. The research depend on representation and calculation the resulted of chemical analysis of 96 groundwater samples collected from 96 pumping well During autumns 2011 from quaternary aquifer. the resulted reviled that; $25 \%$ of groundwater samples within the range of none restriction on use and the rest are margin according TDS content, most of samples are good for irrigation in all soils as they located in classes (C2-S1) and (C3-S1) and suitable for irrigation all crops as belong to SAR values and RSC hazard. But it restricted by boron ion concentration.
\end{abstract}

Keywords: Groundwater Quality; Irrigation; River Nile; Minia; Egypt.

Cite This Article: Mamdouh Salama Morsi. (2018). "GROUNDWATER QUALITY ASSESSMENT FOR IRRIGATION PURPOSES AT THE WESTERN PORTION OF THE RIVER NILE- MINIA DISTRICT- EGYPT.” International Journal of Research Granthaalayah, 6(4), 325-339. https://doi.org/10.29121/granthaalayah.v6.i4.2018.1667.

\section{Introduction}

The suitability of groundwater for irrigation purposes based on important factors which effected and controlled in the kinds and productive of crops. Several authors proposed many different classifications for irrigation water. The quality requirements of irrigation water vary between crops types, drain ability and types of soils and climate. These rigorous universal standards for irrigation water cannot to formula. Important parameter most be taken in consideration for assessment process these are; total dissolved salts (TDS), relative proportion of sodium (SAR), residual sodium carbonate (RSC), concentration of certain trace elements with respect boron. TDS may harm plant growth which can be taken by up Lake through of osmotic pressure or metabolic reactions which change in soil structure, permeability aeration which affect in plant growth. Sodium adsorption ratio (SAR) used to stated the sodality hazard of irrigation water. According this ratio and salinity; US salinity laboratory staff classified irrigation water into four classes $(\mathrm{Cn}$ Sn) which Cn denote conductivity and Sn denote (SAR). Residual sodium carbonate also used to distinguish between different irrigation water classes, where the higher bicarbonate content lead 
to increasing $\mathrm{pH}$ value which lead to dissolution of organic matter, in addition the causes toxicity and effects the mineral nutrition of plants. While boron element is important for plant growth and proper plant nutrition, but the increase over the needed lead to toxic for certain plants. Therefore, plant species vary in both boron requirements and in their tolerance excess boron.

\section{Study Area}

The investigation area is located between El-Edwa and Maghagha cities at north and Deir- Mawas at south at the western portion of the River Nile in Minia district - Egypt. The area covered about $3375 \mathrm{Km}^{2}$, located between latitudes $27^{\circ} 30^{\circ}$ and $28^{\circ} 40^{\circ} \mathrm{N}$ and longitudes $30^{\circ} 30^{\circ}$ and $31^{\circ} 00^{\circ} \mathrm{E}$. and limits by River Nile in east, reclamation and limestone plateau in west. The River Nile forms the main water resource of Minia Governorate (share about 4.32 Billion Cubic meter/ year), 84\% for agriculture for about 437957 fadan, $1.25 \%$ for drinking purposes and the rest are for industrial and other purposes. It is characterized by arid to semi arid climate dry in summer and mild with rare precipitation in winter (EP Minia 2007) Finger (1).

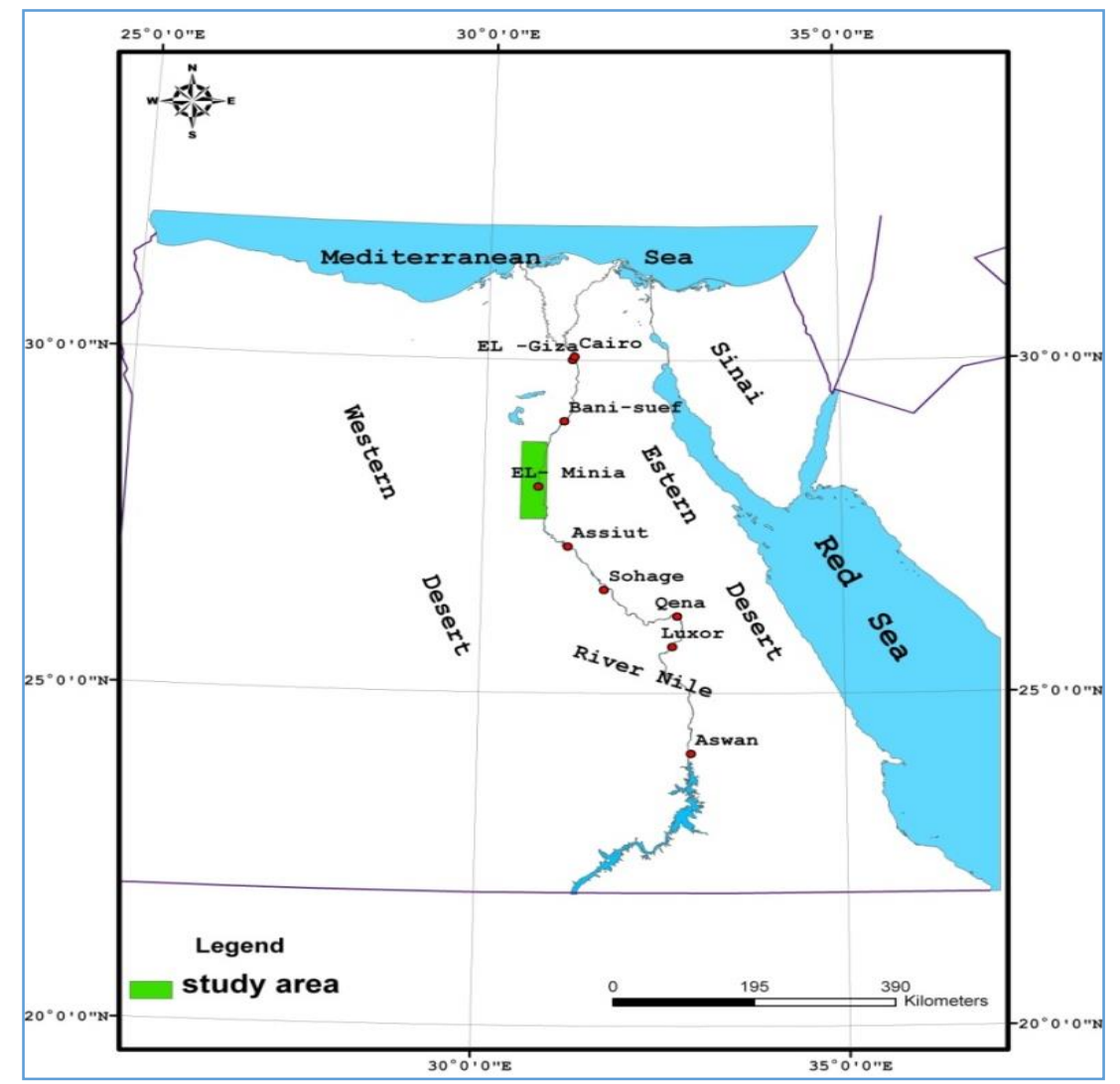

Figure 1: Location map of the study area in Minia district (Morsi 2012)

\section{Material and Method}

This research depend on the representation the published results of chemical analysis of 96 groundwater samples collected from 96 pumping well all over the study area during winter season 2011 from quaternary aquifer by (Morsi 2012) Figure (2). 


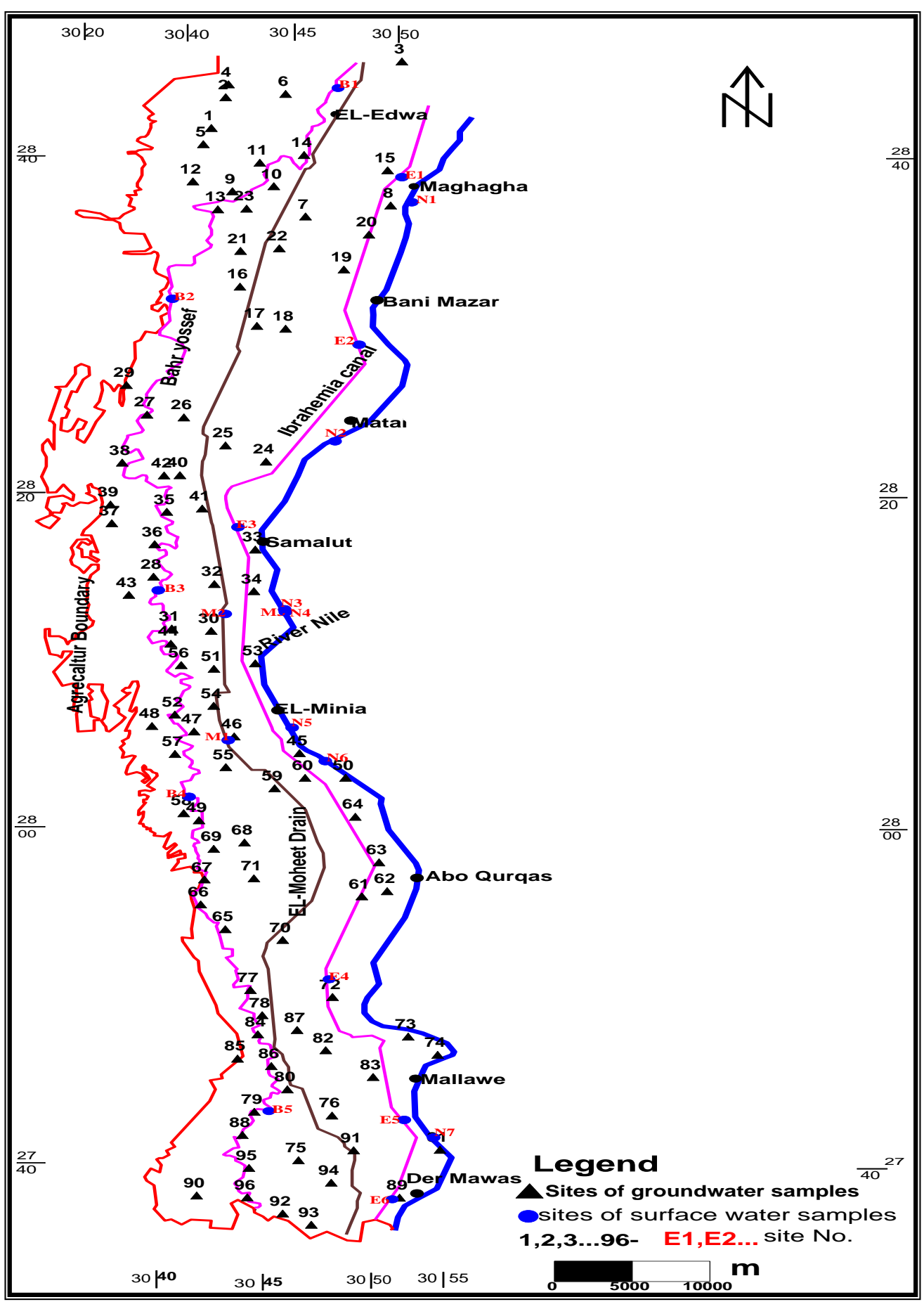

Figure 2: Location of) monitoring pointes of groundwater samples in the study area

\section{Results and Discussion}

The assessment determined by comparing the result chemical analyses of groundwater samples by Food and Agriculture Organization of United Nations guidelines(FAO 1985 and 2010) Table $(1,2)$ for irrigation water and recommended water quality criteria for irrigation by (Ayers, 1977) table (3) 
The application of these standards to the chemical data of the study area revealed that:

\section{The total concentration of dissolved salt (TDS)}

According to the (TDS) concentration, about $25 \%$ of groundwater samples (pumps) are suitable water for irrigation, (within the range of none restriction on use), while about $75 \%$ of the wells pumps are marginal (slight to moderate restriction on use) but others parameters can be controlled in its used.

Fig. (3).

\section{The relative proportion of sodium to other cations}

The exchange of ions alters the physical characteristics of the soil. clay that carries a good excess of $\mathrm{Ca}^{2+}$ or $\mathrm{Mg}^{2+}$ has a good permeability if the same clay takes up $\mathrm{Na}$, it becomes sticky and has very low permeability. It shrinks when dry and becomes difficult to break up by cultivation creating an alkali soil (Mansouir 2010). According to the relative proportion of $\mathrm{Na}^{+}$to the major cations, some classification of surface and groundwater for irrigation purpose are developed as the following:

\section{U.S salinity laboratory staff classification (1954)}

The U.S. salinity laboratory staff classification (1954) is based on the sodium adsorption ratio (SAR), the specific conductance (in micro mhos / $\mathrm{cm}$ ). The sodium adsorption ratio (SAR) is used to estimate the sodality hazard of the Water.

Where $S A R=\frac{N a^{+}}{\sqrt{\frac{1}{2}\left(C a^{2+}+M g^{2+}\right)}}$ and all concentration are in $\mathrm{mg} / \mathrm{L}$

SAR is a measure of the tendency of the irrigation water to the soil clay minerals with sodium ions, sodium clays have poor structure and develop permeability problems (George, 1983). The classes of water quality according to the U.S. salinity laboratory staff method is shown in the table (4). Figs. (4 and 5) show the distribution of SAR values in groundwater samples and their classes in study area.

According to the U.S. salinity laboratory diagram, the water is divided into four classes C1, C2, $\mathrm{C} 3$ and $\mathrm{C} 4$, which denote the conductance, and S1, S2, S3, and S4, which denote (SAR).

The results of applying this classification to the groundwater in study area as the following: Most of the groundwater samples $(100 \%)$ are good water for irrigation purpose [C2 -S1 (34.37\%)], [C3 - S1 (65.63\%)], but [C3 - S1] can be used under specific condition like adequate drainage and leaching Fig. (6).

Table 1: Guidelines for irrigation water are based on (FAO 2010] \& [FAO 1985)

(Handbook 29 and PACE turf observations (2010)

\begin{tabular}{|l|l|l|c|}
\hline \multirow{2}{*}{ Quality parameter } & \multicolumn{3}{|l|}{ Likelihood of soil problems } \\
\cline { 2 - 4 } & low & Medium & High \\
\hline ECw $(\mathrm{ds} / \mathrm{m}, \mathrm{mmhos} / \mathrm{cm})$ & $<0.7$ & $0.7-3.0$ & $>$ \\
\hline TDS(mg/l, mg/l) & $<450$ & $450-2000$ & $>$ \\
\hline SAR 0-3 & ECW $>0.7$ & ECW 0.7-0.2 & ECW $<0.2$ \\
\hline
\end{tabular}




\begin{tabular}{|l|l|l|l|}
\hline SAR 3-6 & ECW $>1.2$ & ECW 1.2- 0.3 & ECW $<0.3$ \\
\hline SAR 6-12 & ECW $>1.9$ & ECW 1.9- 0.5 & ECW $<0.5$ \\
\hline SAR $12-20$ & ECW $>2.9$ & ECW 2.9- 1.3 & ECW $<2.9$ \\
\hline Sodium $\mathrm{Na}(\mathrm{me} / \mathrm{l})$ & $<3$ & $3-9$ & $>9$ \\
\hline Sodium $\mathrm{Na}(\mathrm{mg} / \mathrm{l})$ & $<70$ & $70-200$ & $>200$ \\
\hline RSC $(\mathrm{me} / \mathrm{l})$ & $<1.25$ & $>1.25$ & \multicolumn{1}{|l|}{} \\
\hline Nitrate $\mathrm{NO}_{3}-\mathrm{N}(\mathrm{mg} / \mathrm{l})$ & $<5$ & $5-20$ & $>30$ \\
\hline Ammonium $\mathrm{NH}_{4}-\mathrm{N}(\mathrm{mg} / \mathrm{l})$ & $<5$ & $5-20$ & $>20$ \\
\hline Boron $\mathrm{B}(\mathrm{mg} / \mathrm{l})$ & $<0.5$ & $0.5-3.0$ & $>3.0$ \\
\hline Bicarbonate $\mathrm{HCO}_{3}(\mathrm{me} / \mathrm{l})$ & $<1.5$ & $1.5-8.5$ & $>8.5$ \\
\hline Bicarbonate $\mathrm{HCo}_{3}(\mathrm{mg} / \mathrm{l})$ & 92 & $92-520$ & $>520$ \\
\hline Chloride $\mathrm{Cl}(\mathrm{me} / \mathrm{l})$ & $<3$ & $>3$ & \\
\hline Chloride $\mathrm{CL}(\mathrm{mg} / \mathrm{l})$ & $<105$ & $>105$ & \\
\hline
\end{tabular}

Table 2: guidelines for interpretation of water quality for irrigation (FAO 2010] \& [FAO 1985)

\begin{tabular}{|c|c|c|c|c|}
\hline \multirow{2}{*}{$\begin{array}{l}\text { Potential irrigation water quality } \\
\text { problem }\end{array}$} & \multirow[t]{2}{*}{ Parameter } & \multicolumn{3}{|c|}{ Degree of restriction on use } \\
\hline & & None & Slight to & Severe \\
\hline \multirow{2}{*}{ Salinity(affects crop water availability) } & ECiw & $<0.7$ & $0.7-3.0$ & $>3.0$ \\
\hline & Or TDS (mg/l) & $<450$ & $450-2,000$ & $>$ \\
\hline \multirow{6}{*}{$\begin{array}{l}\text { Infiltration } \\
\text { (affects water infiltration rate, evaluated by } \\
\text { using ECiw and SAR together) }\end{array}$} & SAR & \multicolumn{3}{|c|}{ ECiw $(\mathrm{mmho} / \mathrm{cm})$} \\
\hline & $0-3$ & $>0.7$ & $0.7-0.2$ & $<0.2$ \\
\hline & $3-6$ & $>1.2$ & $1.2-0.3$ & $<0.3$ \\
\hline & $6-12$ & $>1.9$ & $1.9-0.5$ & $<0.5$ \\
\hline & $12-20$ & $>2.9$ & $2.9-1.3$ & $<1.3$ \\
\hline & $20-40$ & $>5.0$ & $5.0-2.9$ & $<2.9$ \\
\hline \multicolumn{5}{|l|}{ Specific ion toxicity } \\
\hline$\left(\mathrm{HCO}_{3}{ }^{-}\right)$Bicarbonate & $\mathrm{meq} / \mathrm{l}$ & $<1.5$ & $1.5-8.5$ & $>8.5$ \\
\hline
\end{tabular}

Table 3: Recommended water quality criteria for irrigation [Ayers, 1977]

\begin{tabular}{|l|l|l|l|l|l|}
\hline \multirow{2}{*}{ constituents } & \multirow{2}{*}{ Unit } & \multicolumn{3}{|l|}{ Suitability for irrigation } & Specific crops affected \\
\cline { 3 - 5 } & & Suitable & Marginal & Unsuitable & \\
\hline EC & $\mu \mathrm{mmhos} / \mathrm{cm}$ & $<750$ & $750-3000$ & $>3000$ & \\
\hline $\mathrm{TDS}$ & $\mathrm{mg} / \mathrm{l}$ & $<250$ & $500-2000$ & $>2000$ & \\
\hline $\mathrm{B}^{++}$ & $\mathrm{mg} / \mathrm{l}$ & $<0.5$ & $0.5-2$ & $>2$ & Fruit and citrius trees 5-1 \\
\hline $\mathrm{CL}^{-}$ & $\mathrm{mg} / \mathrm{l}$ & $<142$ & $142-355$ & $>355$ & Tree crops and ornamentals \\
\hline $\mathrm{SAR}$ & & $<3$ & $3-9$ & $>9$ & Tree crops- root adsorption \\
\hline $\mathrm{SO}_{4}^{-}$ & $\mathrm{mg} / \mathrm{l}$ & $<350$ & $350-600$ & $>600$ & \\
\hline
\end{tabular}

Table 4: The water quality classes according to [George, 1983]

\begin{tabular}{|l|l|l|l|}
\hline conductivity & quality & Range & Usage \\
\hline C1 & Low & $100-$ & Can be used for irrigation of most crops in most soils with \\
\hline C2 & Medium & $250-$ & Can be used if a moderate amount of leaching occurs \\
\hline C3 & High & $750-$ & Canot be used on soil with restricted Drainage even with \\
\hline C4 & Very & $>2250$ & Is not suitable for irrigation under ordinary conditions but \\
\hline SAR & quality & Range & Usage \\
\hline
\end{tabular}




\begin{tabular}{|l|l|l|l|}
\hline S1 & Low & $0-10$ & Can be used for irrigation of almost all soils with little \\
\hline S2 & Medium & $10-18$ & Will represents an appreciable sodium hazard in fine- \\
\hline S3 & High & $18-26$ & May produce harmful levels of exchangeable sodium in \\
\hline S4 & Very & $26-$ & Is generally unsatisfactory for irrigation purposes except at \\
\hline
\end{tabular}

Note; 1 - the C2-S3 and C3-S3 water can be improved by adding gypsum to the soil.

2- The C2-S4 may be improved by the addition of gypsum to the water.

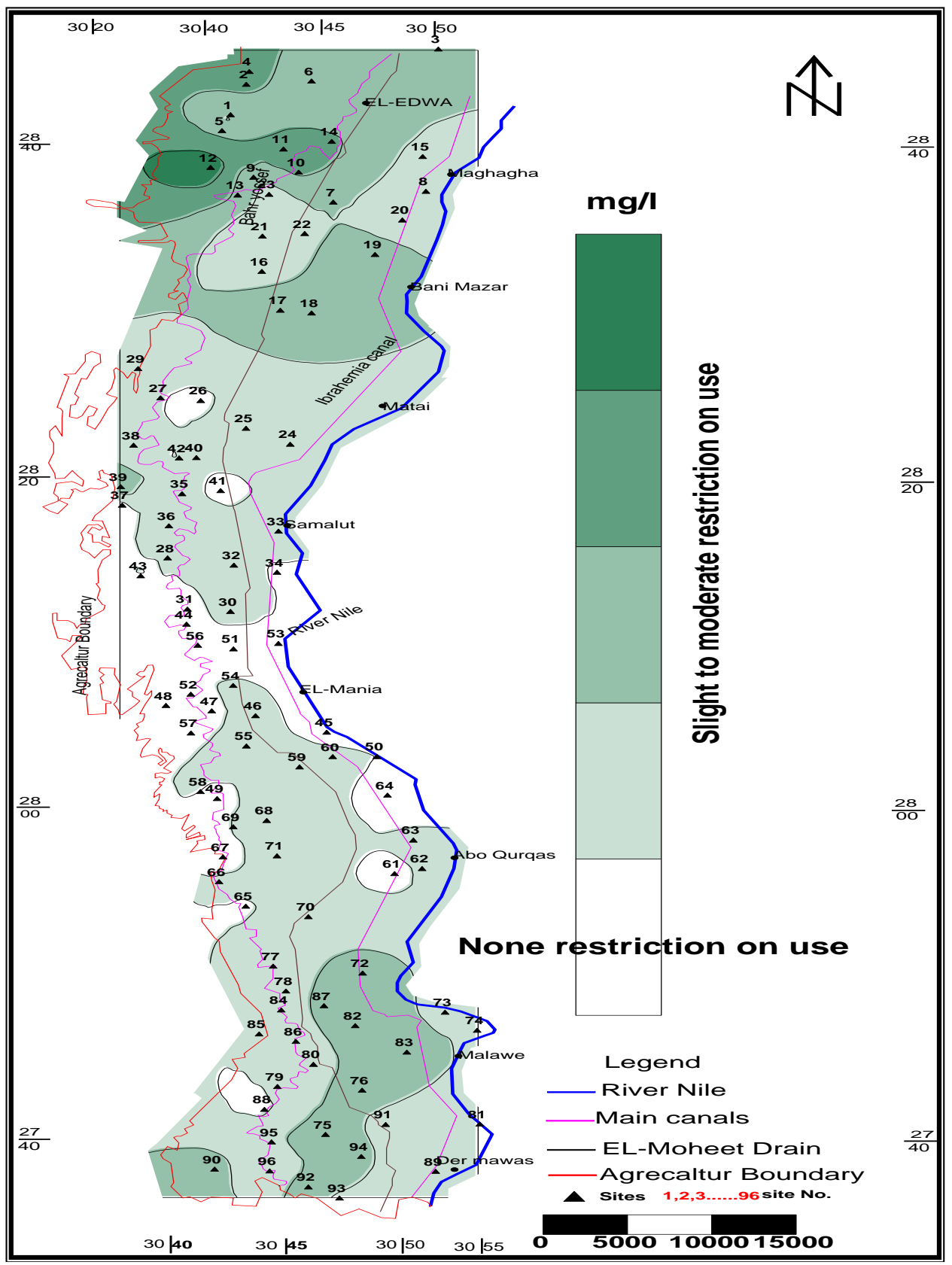

Figure 3: Water quality zonation map for irrigation purposes according the total concentration of dissolved salt (TDS) in groundwater samples of study area 


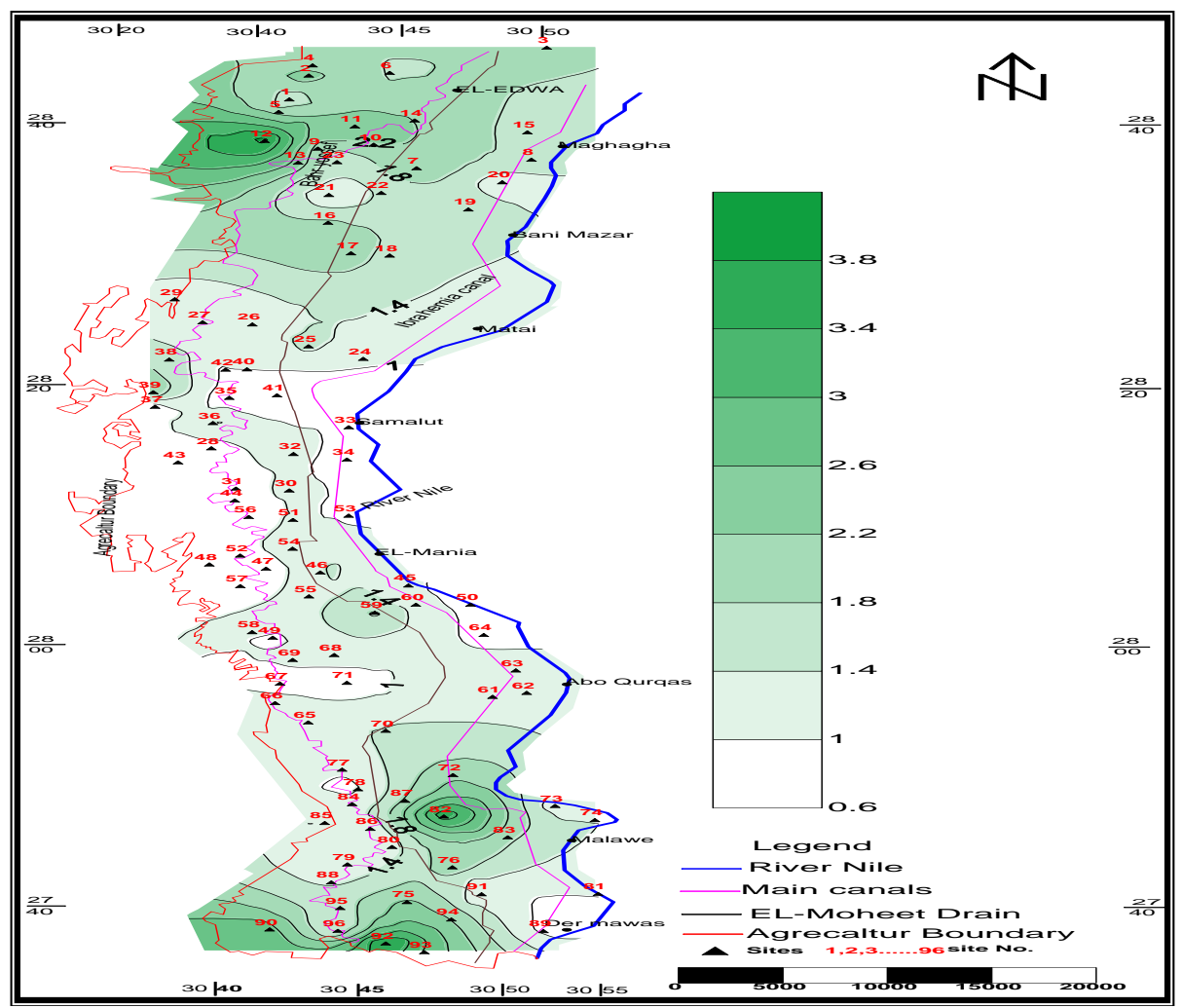

Figure 4: Distribution of SAR concentration contour map of groundwater samples in study are

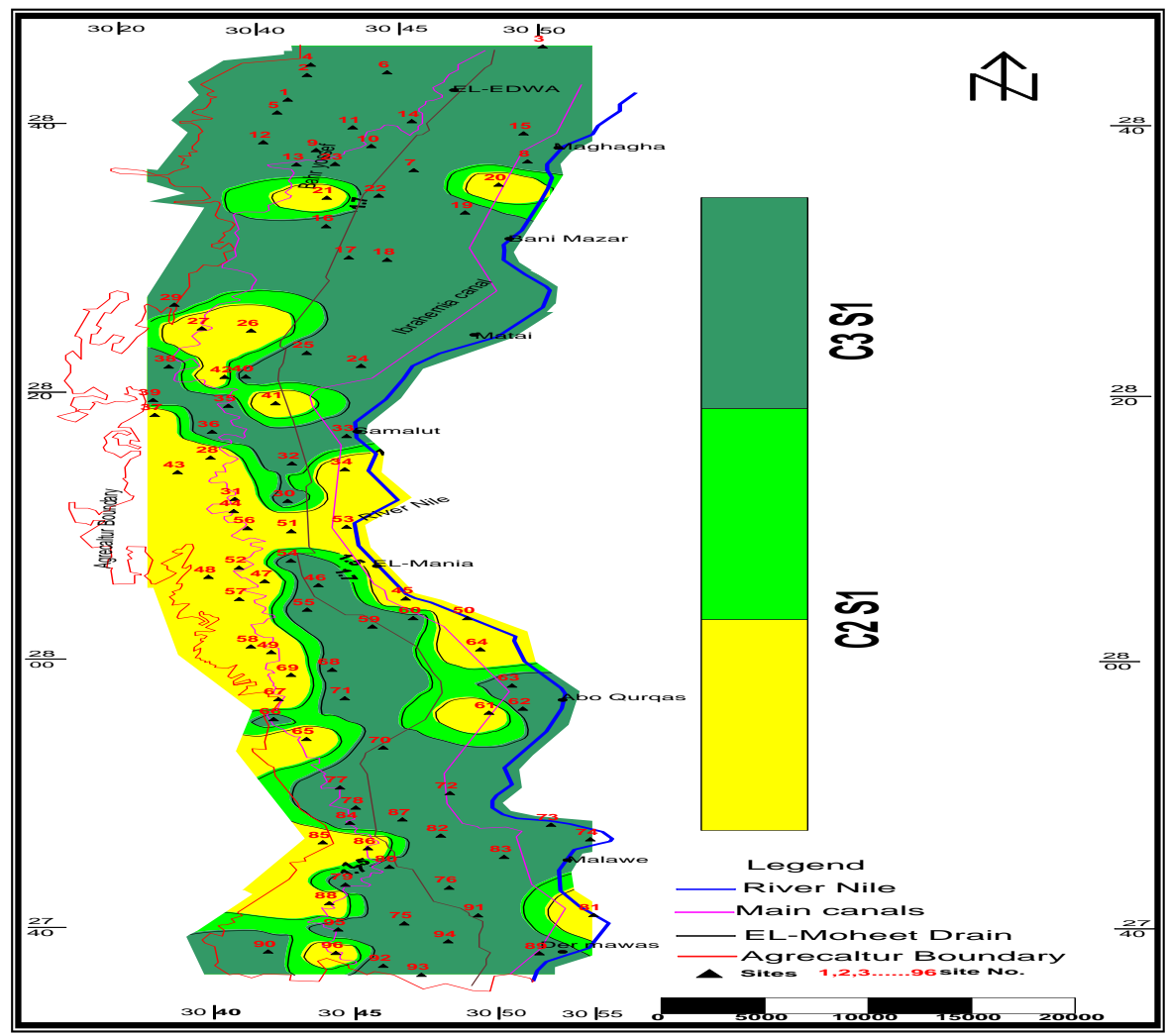

Figure 5: Classes' contour map of Groundwater samples in study area 

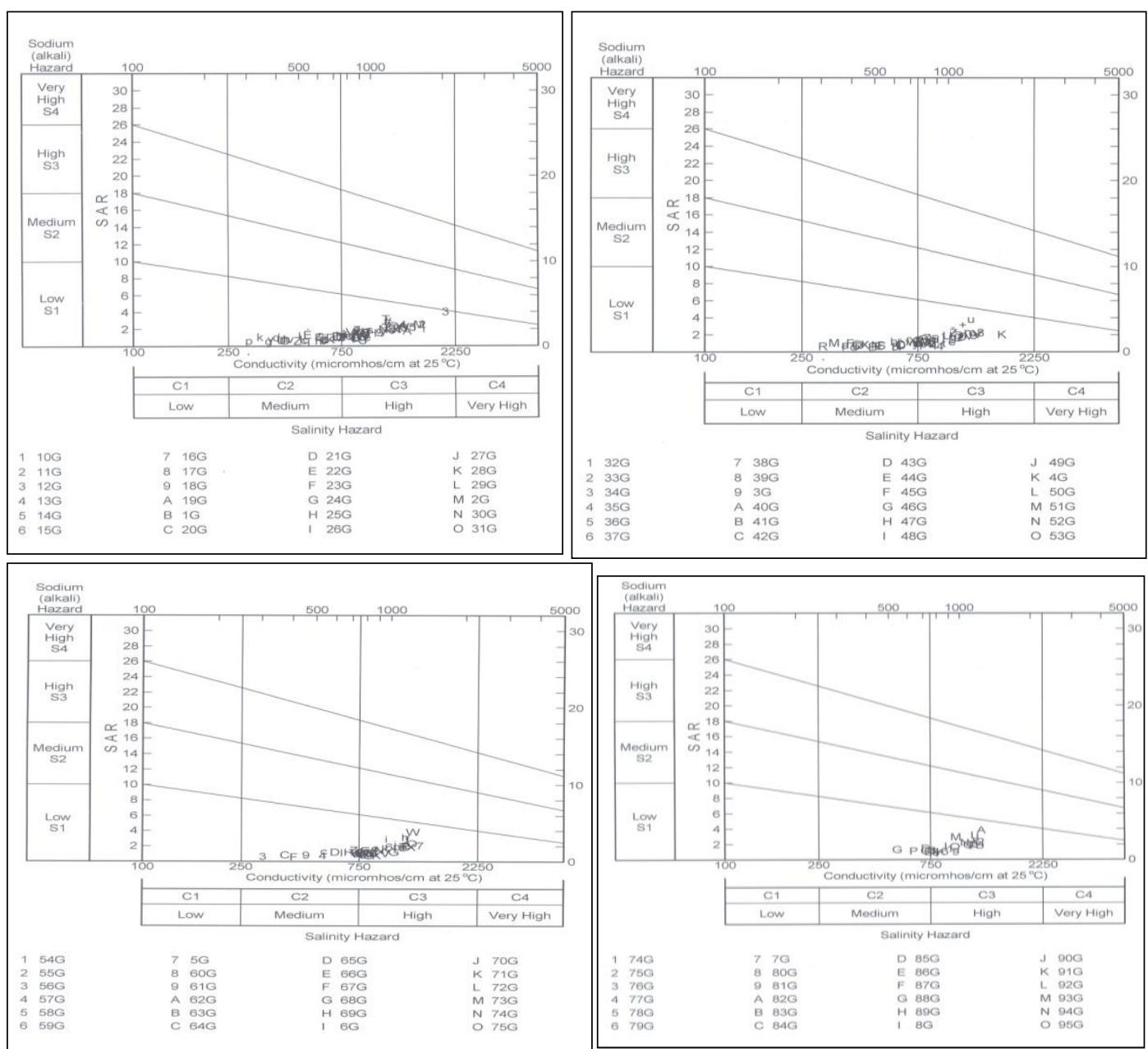

Figure 6: Classification of groundwater samples according [US Salinity laboratory Staff (1954)]

Evaluation for irrigation on basis of the crops and their salt tolerance

Groundwater samples (100\%) are suitable for irrigation of all crops [sensitive, semi - tolerant and tolerant]. Table: (5) shows crops and their salt tolerance, where the salinities lower than 4 mmhos / cm (Richard, 1954).

Table 5: Crops and their salt tolerance (Richard, 1954)

\begin{tabular}{|c|c|c|}
\hline $\begin{array}{l}\text { Sensitive crops } \\
<4 \mathrm{mmhos} / \mathrm{cm}\end{array}$ & $\begin{array}{l}\text { Semi-tolerant crops salinity } 4-10 \\
\text { mmhos / cm }\end{array}$ & $\begin{array}{l}\text { Tolerant crops } \\
10-16 \text { mmhos / cm }\end{array}$ \\
\hline $\begin{array}{l}\text { fruits ;- } \\
\text { Orchards, orange, apple, pear, } \\
\text { almond, beach, Indian lemon, } \\
\text { apricot and mango. }\end{array}$ & Figs, grapes , and pomegranates & $\begin{array}{l}\text { Live, guavas and } \\
\text { date palm. }\end{array}$ \\
\hline $\begin{array}{l}\text { Vegetables } \\
\text { Celery, radish and strawberry. }\end{array}$ & $\begin{array}{l}\text { Cauliflower, green pepper, tomato, } \\
\text { potatoes, lettuces, carrot, onion peas, } \\
\text { squashes cucumber and watermelon. }\end{array}$ & Peanut, spinach. \\
\hline $\begin{array}{l}\text { Field crops; } \\
\text { beans }\end{array}$ & $\begin{array}{l}\text { Sunflower, peanut, wheat, cesaium, rice } \\
\text { and sorghum. }\end{array}$ & $\begin{array}{l}\text { Cotton, sugar, beat } \\
\text { clover, barley and } \\
\text { cereals. }\end{array}$ \\
\hline
\end{tabular}




\section{Residual sodium carbonates [Eaton's classification, [Eaton, 1950]}

When the sum of carbonate and bicarbonate is in excess of calcium and magnesium, there is an almost complete precipitation of the latter [Eaton, 1950]. This can caused an in increase in the proportionate amount of sodium, and so the effect on the soil is high sodium content. The term residual sodium carbonates (RSC) is defined as follows

$$
\mathrm{RSC}=\left(\mathrm{CO}_{3}^{2+}+\mathrm{HCO}_{3}^{-}\right)-\left(\mathrm{Ca}^{2+}+\mathrm{Mg}^{2+}\right) \text { all in meq/L }
$$

The (RSC) is used distinguish between the different water classes for irrigation purposes because the high concentration of bicarbonate leads to an increase in the $\mathrm{PH}$ value, which causes the dissolution of the organic matter. Moreover, the high concentration of the bicarbonate ions in the irrigation water leads to its toxicity and affects the mineral nutrition of plants. Table (7-11) [Eaton, 1950]

Table 7-11: Eaton classification [Eaton, 1950] based on (RSC) in epm

\begin{tabular}{|l|l|}
\hline Values of RSC in epm & Suitability of water samples for irrigation \\
\hline$<1.25$ & Safe \\
\hline $1.25-2.5$ & Marginal \\
\hline$>2.5$ & Unsuitable \\
\hline
\end{tabular}

Groundwater samples Fig. (7) Also have RSC values less than 1.25 epm. They belong to the possibly safe water for irrigation due as it is free from residual sodium carbonate (RSC) hazard.

\section{Boron contents $\left(\mathbf{B}^{3+}\right)$}

Boron has largely attracted the attention of agriculturists, because of its strong relationship to plant growth. So it should be taken into consideration in evaluating of water quality for irrigation. Generally, boron is an essential micro nutrient to proper plant nutrition; however, a small excess over the needed amount is toxic to some plants. [Leaden et al, 1990] give a classification of boron content due to its importance for the plant growth and its effect on many of the physiological activities of plant tissue Table: (6 and 7). Therefore, plant species vary in both boron requirement and also in their tolerance excess boron Fig. (8).

According to [Leaden et al, 1990] which depended on boron content can be classified groundwater in study area as the following:

The groundwater samples, Fig.(8) showed about (57.3\%) have $\mathrm{B}^{2+}$ values less than $0.33 \mathrm{mg} / \mathrm{l}$ are suitable for irrigation of all crops (excellent), while about $(32.3 \%)$ of groundwater samples have $\mathrm{B}^{2+}$ values between $0.33 \mathrm{mg} / \mathrm{l}$ and $0.67 \mathrm{mg} / \mathrm{l}$ are (good) for irrigation of Sensitive Crop group and excellent for irrigation of semi- tolerant and tolerant crops. and about (10.4\%) of groundwater samples have $\mathrm{B}^{2+}$ values between $0.67 \mathrm{mg} / \mathrm{l}$ and $0.96 \mathrm{mg} / \mathrm{l}$ are (excellent to good) for irrigation of Tolerant Crop group, and good for irrigation Sensitive Crop group while permissible for irrigation of Sensitive Crop group. 
Table 6: Limits of boron in irrigation water [Leaden et al, 1990] permissible limits boron (in

\begin{tabular}{|l|l|l|l|}
\hline \multirow{2}{*}{ Class of water } & Crop group \\
\cline { 2 - 5 } & Sensitive & Semi- tolerant & Tolerant \\
\hline Excellent & $<0.33$ & $<0.67$ & $<1.00$ \\
\hline Good & 0.33 to 0.67 & 0.67 to 1.33 & 1.00 to 2.00 \\
\hline Permissible & 0.67 to 1.0 & 1.33 to 2.00 & 2.00 to 3.00 \\
\hline Doubtful & 1.0 to 1.25 & 2.00 to 2.5 & 3.00 to 3.75 \\
\hline Unsuitable & $>1.25$ & $>2.5$ & $>3.75$ \\
\hline
\end{tabular}

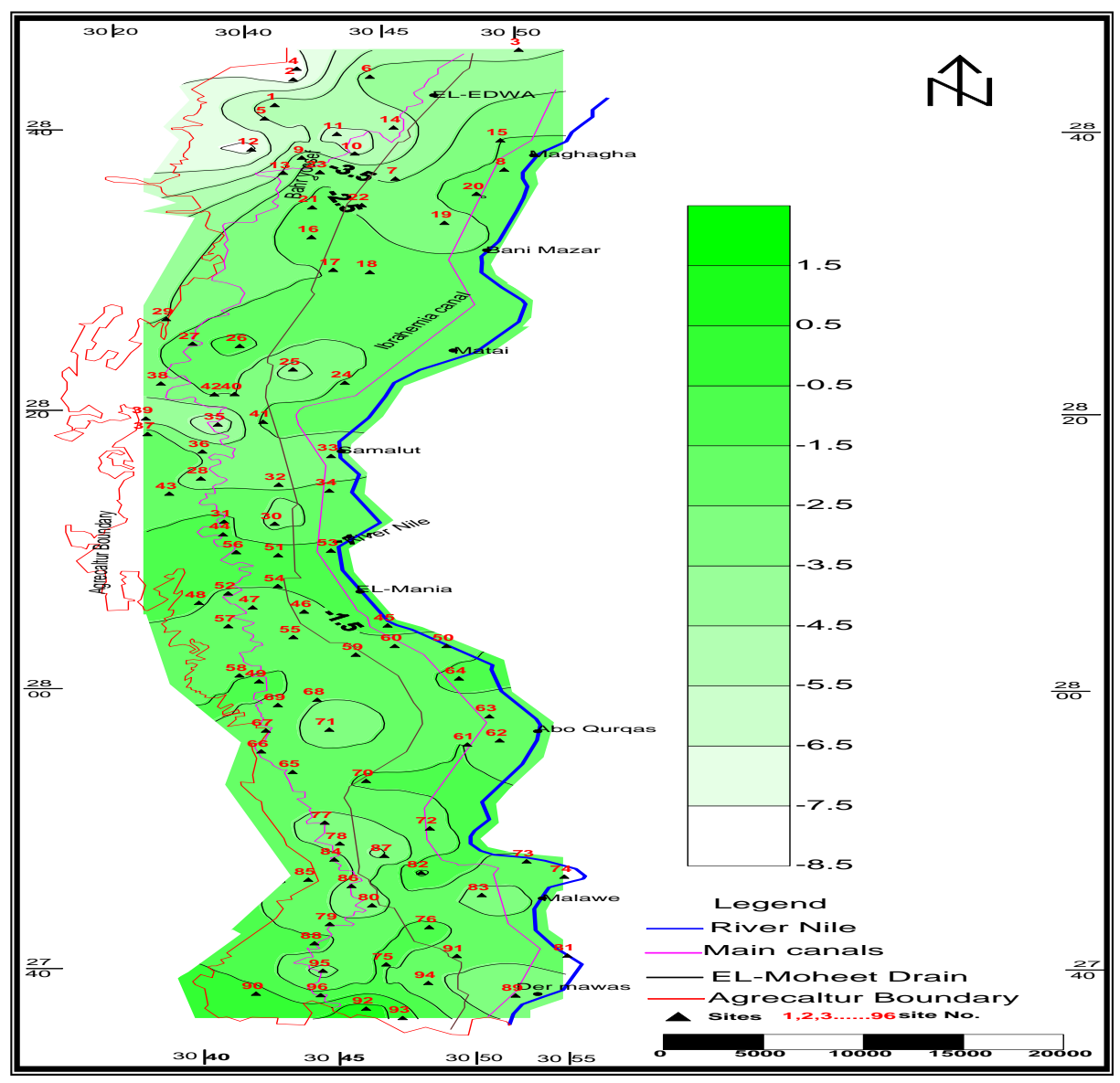

Figure 7: Distribution of RSC concentration contour map of groundwater samples in study area 


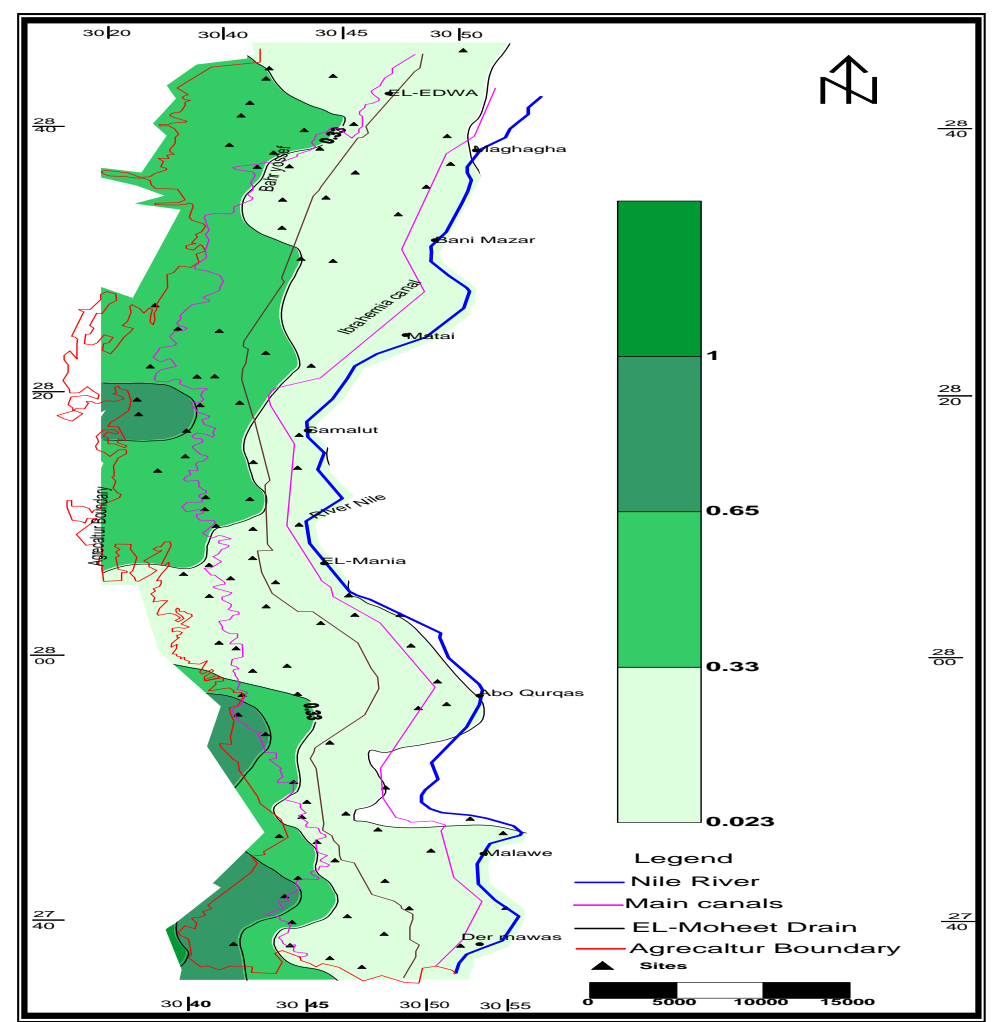

Figure 8: Distribution of Boron concentration contour map of Groundwater samples in study area

Table 7: Crop groups of boron tolerance [Leaden et al, 1990]

\begin{tabular}{|c|c|c|}
\hline Sensitive & Semi tolerant & Tolerant \\
\hline Pecan & Sunflower (native) & Athel ( tamarix aphylly) \\
\hline walnut(black, Persian or English), & Potato & Asparagus \\
\hline Jerusalem - artichoke & Cotton ( Acala and pima) & Palm( phoenix canariensis) \\
\hline Navy bean & Tomato & Date palm (p.dactylifera) \\
\hline Plum & Sweet pea & Sugar beet \\
\hline Pear & Radish & Mangel \\
\hline Apple & Field pea & Garden beet \\
\hline Grape ( sultania and Malaga) & Ragged robin rose & Alfalfa \\
\hline Kadota fig & Olive & Gladiolus \\
\hline Persimmon & Barley & Broad bean \\
\hline Cherry & Wheat & Onion \\
\hline Peach & Corn & Turnip \\
\hline Apricot & Milo & Cabbage \\
\hline Thom less blackberry & Oat & Lettuce \\
\hline Orange & Zinnia & Carrot \\
\hline Avocado & Pumpkin & \\
\hline Grapefruit & Bell pepper & \\
\hline Lemon & Sweet potato & \\
\hline
\end{tabular}


Evaluations for irrigation according to the minor and trace elements concentration

Recommendation for maximum concentration of phytoxic elements in irrigation water was presented by [Rowe et al, 1990), table (8).

According to this recommended limit of [Rowe et al, 1990), can be detected the following:

Groundwater samples, $(87.5 \%)$ are suitable for irrigation because its have concentration below detection limits. while the rest $(12.5 \%)$ have a high value of $\mathrm{Ni}$, at sites $(4,6)$ and $\mathrm{B}$ at sites $(35$, $36,37,39,65,66,76,79,88$ and 90$)$.

In conclusion, the evaluation of Groundwater samples reflect that locale pollution at the minted sites, about (12.5\%) from the total groundwater samples, and the rest have concentration of trace elements below detection limits reflects that no pollution these sites Fig. (9).

Table 8: Recommended limits for minor and trace constituents in reclaimed water for irrigation (Adapted from [Rowe et al, 1990)

\begin{tabular}{|c|c|c|c|}
\hline Constituent & $\begin{array}{l}\text { Long -term } \\
\text { use }(\mathrm{mg} / \mathrm{L})\end{array}$ & $\begin{array}{l}\text { Short -term } \\
\text { use }(\mathrm{mg} / \mathrm{L})\end{array}$ & Remarks \\
\hline $\begin{array}{l}\text { Aluminum } \\
\text { (Al) }\end{array}$ & 5,0 & 20 & $\begin{array}{l}\text { Can cause non productivity in acid } \\
\text { soils, but soils at } \mathrm{pH} 5.5 \text { to } 8.0 \text { will } \\
\text { precipitate the ion and eliminate } \\
\text { toxicity }\end{array}$ \\
\hline Arsenic (As) & 0.1 & 2.0 & $\begin{array}{l}\text { Toxicity to plants varies widely, } \\
\text { ranging from } 12 \mathrm{mg} / \mathrm{L} \text { for Sudan } \\
\text { grass to less than } 0.05 \mathrm{mg} / \mathrm{L} \text { for } \\
\text { rice }\end{array}$ \\
\hline $\begin{array}{l}\text { Beryllium } \\
\text { (Be) }\end{array}$ & 0.1 & 0.5 & $\begin{array}{l}\text { Toxicity to plants varies widely, } \\
\text { ranging from } 5 \mathrm{mg} / \mathrm{L} \text { for kale to } 0.5 \\
\mathrm{mg} / \mathrm{L} \text { for bush beans }\end{array}$ \\
\hline Boron (B) & 0.75 & 2.0 & $\begin{array}{l}\text { Essential to plant growth, with } \\
\text { optimum yields for many obtained } \\
\text { at a few-tenths } \mathrm{mg} / \mathrm{L} \text { in nutrient } \\
\text { solutions. Toxic to many sensitive } \\
\text { plants (e.g., citrus) at } 1 \mathrm{mg} / \mathrm{L} \text {. Most } \\
\text { grasses relatively tolerant at } 2.0 \text { to } \\
10 \mathrm{mg} / \mathrm{L} \text {. }\end{array}$ \\
\hline $\begin{array}{l}\text { Cadmium } \\
\text { (Cd) }\end{array}$ & 0.01 & 0.05 & $\begin{array}{l}\text { Toxic to beans, beets, and turnips } \\
\text { at concentrations as low as } 0.1 \\
\mathrm{mg} / \mathrm{L} \text { in nutrient solution. } \\
\text { Conservative limits recommended }\end{array}$ \\
\hline $\begin{array}{l}\text { Chromium } \\
(\mathrm{Cr})\end{array}$ & 0.1 & 1.0 & $\begin{array}{l}\text { Not generally recognized as } \\
\text { essential growth element. } \\
\text { Conservative limits recommended } \\
\text { due to lack of knowledge on } \\
\text { toxicity to plants }\end{array}$ \\
\hline Cobalt (Co) & 0.05 & 5.0 & $\begin{array}{l}\text { Toxic to tomato plants at } 0.1 \mathrm{mg} / \mathrm{L} \\
\text { in nutrient solution. Tends to be }\end{array}$ \\
\hline
\end{tabular}




\begin{tabular}{|c|c|c|c|}
\hline Constituent & $\begin{array}{l}\text { Long -term } \\
\text { use }(\mathrm{mg} / \mathrm{L})\end{array}$ & $\begin{array}{l}\text { Short -term } \\
\text { use }(\mathrm{mg} / \mathrm{L})\end{array}$ & Remarks \\
\hline & & & $\begin{array}{l}\text { inactivated by neutral and alkaline } \\
\text { soils. }\end{array}$ \\
\hline Copper $(\mathrm{Cu})$ & 0.2 & 5.0 & $\begin{array}{l}\text { Toxic to a number of plants at } 0.1 \\
\text { to } 1.0 \mathrm{mg} / \mathrm{L} \text { in nutrient solution }\end{array}$ \\
\hline Fluoride (F) & 1.0 & 15.0 & $\begin{array}{l}\text { Inactivated by neutral and alkaline } \\
\text { soils }\end{array}$ \\
\hline Iron $(\mathrm{Fe})$ & 5.0 & 20.0 & $\begin{array}{l}\text { Not toxic to plants in aerated soils, } \\
\text { but can contribute to soil } \\
\text { acidification and loss of essential } \\
\text { phosphorus and molybdenum }\end{array}$ \\
\hline
\end{tabular}

Table 8: Cont.

\begin{tabular}{|c|c|c|c|}
\hline Constituent & $\begin{array}{l}\text { Long -term } \\
\text { use }(\mathrm{mg} / \mathrm{L})\end{array}$ & $\begin{array}{l}\text { Short -term } \\
\text { use }(\mathrm{mg} / \mathrm{L})\end{array}$ & Remarks \\
\hline Lead $(\mathrm{Pb})$ & 5.0 & 10.0 & $\begin{array}{l}\text { Can inhibit plant cell growth at } \\
\text { very high concentrations }\end{array}$ \\
\hline Lithium (Li) & 2.5 & 2.5 & $\begin{array}{l}\text { Tolerated by most crops at up to } 5 \\
\mathrm{mg} / \mathrm{L} \text {; mobile in soil. Toxic to } \\
\text { citrus at low doses « recommended } \\
\text { limit is } 0.075 \mathrm{mg} / \mathrm{L} \text {. }\end{array}$ \\
\hline $\begin{array}{l}\text { Manganese } \\
(\mathrm{Mn})\end{array}$ & 0.2 & 10.0 & $\begin{array}{l}\text { Toxic to a number of crops at few- } \\
\text { tenths to a few } \mathrm{mg} / \mathrm{L} \text { in acid soils. }\end{array}$ \\
\hline $\begin{array}{l}\text { Molybdenum } \\
\text { (Mo) }\end{array}$ & 0.01 & 0.05 & $\begin{array}{l}\text { Nontoxic to plants at normal } \\
\text { concentrations in soil and water. } \\
\text { Can be toxic to livestock if forage } \\
\text { is grown in soils with high levels } \\
\text { of available molybdenum }\end{array}$ \\
\hline Nickel (Ni) & 0.2 & 2.0 & $\begin{array}{l}\text { Toxic to a number of plants at } 0.5 \\
\text { to } 1.0 \mathrm{mg} / \mathrm{L} \text {; reduced toxicity at } \\
\text { neutral or alkaline } \mathrm{pH} \text {. }\end{array}$ \\
\hline Selenium (Se) & 0.02 & 0.02 & $\begin{array}{l}\text { Toxic to plants at low } \\
\text { concentrations and to livestock if } \\
\text { forage is grown in soils with low } \\
\text { levels of added selenium }\end{array}$ \\
\hline $\begin{array}{l}\text { Vanadium } \\
\text { (V) }\end{array}$ & 0.1 & 1.0 & $\begin{array}{l}\text { Toxic to many plants at relatively } \\
\text { low concentrations }\end{array}$ \\
\hline Zinc (Zn) & 2.0 & 10.0 & $\begin{array}{l}\text { Toxic to many plants at widely } \\
\text { varying concentrations; reduced } \\
\text { toxicity at increased pH (6 or } \\
\text { above) and in fine-textured or } \\
\text { organic soils }\end{array}$ \\
\hline
\end{tabular}




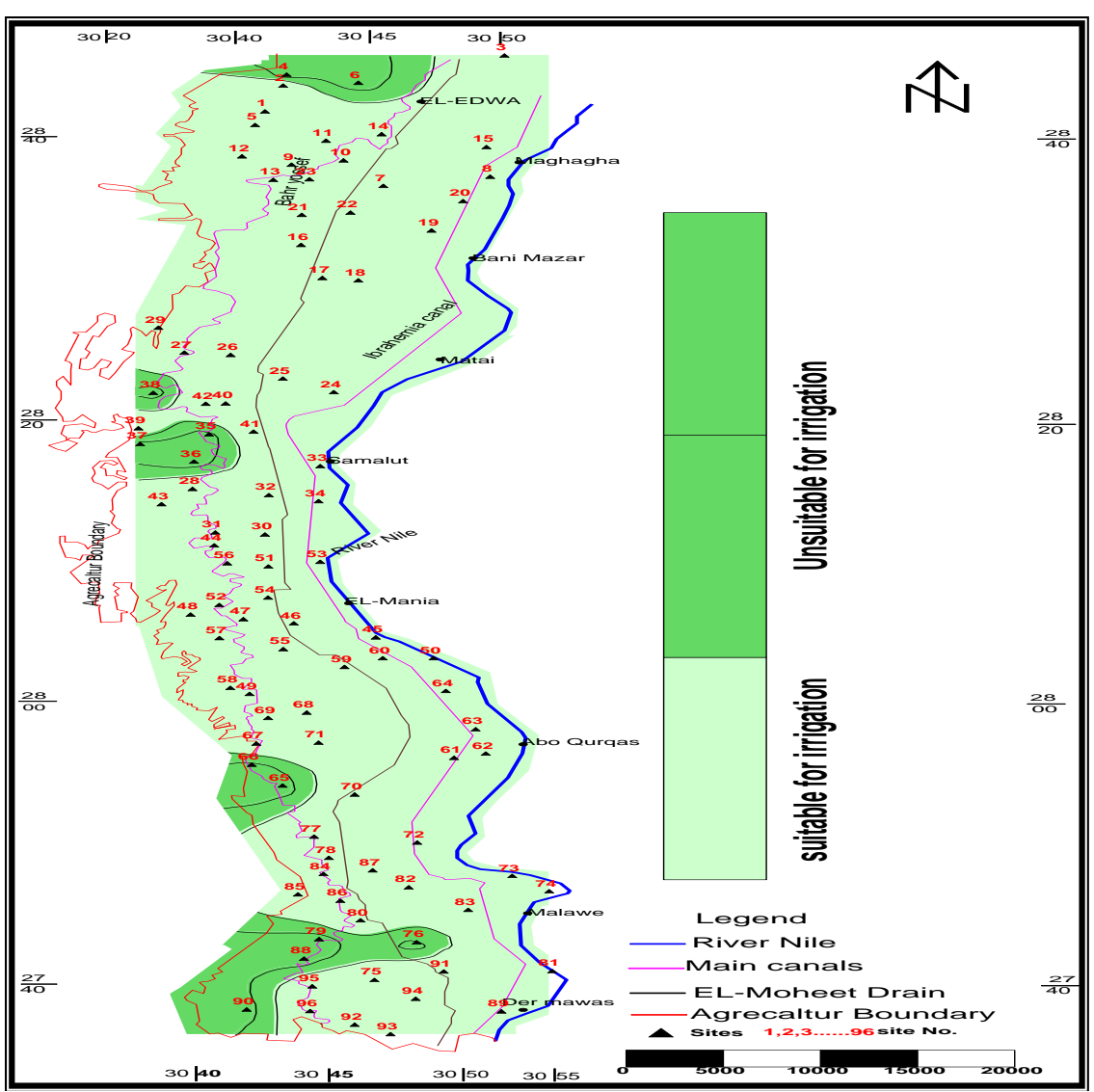

Figure 9: Evaluation contour map of ground water samples for irrigation purpose according to trace elements concentration in study area

\section{Summary}

According to the (TDS) concentration, groundwater about $25 \%$ of the pumps are suitable water for irrigation, (within the range of None restriction on use), while about $75 \%$ of the wells pumps are marginal (slight to moderate restriction on use).

According to U.S salinity laboratory staff classification (Richards, 1954) groundwater, most of the groundwater samples $(100 \%)$ are good water for irrigation purpose [C2 -S1 (34.37\%)], [C3 - S1 $(65.63 \%)]$.

According to the crops and their salt tolerance; groundwater samples (100\%) are suitable for irrigation of all crops [sensitive, semi - tolerant and tolerant].

According residual sodium carbonate [Eaton's classification, 1950] Groundwater samples belong to the possibly safe water for irrigation uses as showing in details in the figures.

Consequently, we recommend selecting the suitable kind of crops for each area based on the hazards of the TDS, B contents and SAR, and RSC values and their effect on plant growth and its products in relation to soil problems. More details studies the soil characters and the suitable type 
of crops and irrigation and the available class of groundwater in the area a strong control on the use of fertilizers and pesticides in the agriculture purposes,

\section{References}

[1] Ayers, R. S., (1977). "QUALITY OF WATER FOR IRRIGATION "Journal of the Irrigation and Drainage Division ASCE, 103: No. IR2.

[2] Eaton, F.M. (1950). "SIGNIFICANCE OF CARBONATES IN IRRIGATION WATER' S". Soil Sci., 69: No. 2, pp. 127 - 128.

[3] Eg. St. (1995). "EGYPTION STANDARS FOR DRINKING WATER AND DOMESTIC USES Decree of Health Minister (No. 108) / 1995" (in Arabic).

[4] Eg. St. (2007). "EGYPTION STANDARS FOR DRINKING WATER AND DOMESTIC USES" Decree of Health Minister (No. 458) / 2007 (in Arabic).

[5] E P Minia (2007). "ENVIRONMENTAL PROFILE OF EL-MINIA GOVERNORATE 2007" Egyptian Environmental Affair Agency. (in Arabic)

[6] FAO (1985). "FOOD AND AGRICULTURE ORGANIZATION OF THE UNITED NATIONS (FAO) (1985)" Irrigation and Drainage. Bull. NO 29 Rev. I.

[7] FAO (2010). FOOD AND AGRICULTURE ORGANIZATION OF THE UNITED NATIONS (FAO) handbook 29 and PACE Turf Observations (2010). Water quality guidelines. PACE Turf, San Diego CA 92109.

[8] George, P. R. (1983). “AGRICALTURAL WATER QUALITY CRITERIA IRRIGATION ASPECTS" Dep. of Agriculture Western Australia, Resource Management Technical Report No. 30.

[9] Leaden, V. F.; Troise, F. L. and Todd, D. K. (1990). “THE WATER ENCYCLOPEDIA. Lewis Publishers, $808 \mathrm{p}$.

[10] Mansouir, M. R. (2010). "EVALUATION OF WATER RESOURCES OF THE NORTHERN COAST OF SINAI. EGYPT. M Sc. Thesis, Geol. dept. Faculty of Science, Cairo University.

[11] Morsi M. S., (2012). "ENVIRONMENTAL IMPACT OF ANTHOPOGENIC ACTIVITIES ON THE SURFACE AND GROUNDWATER SYSTEM IN THE WESTERN PART OF THE RIVER NILE IN MINIA GOVERNORATE” M Sc. Thesis 2012 Faculty of Science. geol. Dep. Minia University.

[12] Richard, I. A. (1954). "DIAGNOSIS AND IMPORTANT OF SALINE AND ALKALI SOILS ". US Department of Agricultural handbook, 60: $160 \mathrm{p}$.

[13] Rowe, D. R. and Abdel-Magid, I. M. (1995). "HANDBOOK OF WAST WATER RECLAMATION AND REUSE". CRC Press Inc., $550 \mathrm{p}$.

[14] US Salinity Laboratory Staff (1954). "DIAGNOSIS AND IMPORTANT OF SALINE AND ALKALI SOILS". US dept. Agriculture Handbook No.60: 160 pp

[15] WHO (2004). “GUIDELINES FOR DRINKINKING WATER QUALITY” 3rd ed., Volume 1: Recommendations. World Health Organization (WHO), Geneva.

*Corresponding author.

E-mail address: Geo_mamdoh@yahoo.com 